Georgia State University

ScholarWorks @ Georgia State University

4-1-2009

\title{
The Impact of Public Library Use on Reading, Television, and Academic Outcomes
}

Rachana Bhatt

Georgia State University, rbhatt@gsu.edu

Follow this and additional works at: https://scholarworks.gsu.edu/uwrg_workingpapers

\section{Recommended Citation}

Bhatt, Rachana, "The Impact of Public Library Use on Reading, Television, and Academic Outcomes" (2009). UWRG Working Papers. 155.

https://scholarworks.gsu.edu/uwrg_workingpapers/155

This Article is brought to you for free and open access by the Usery Workplace Research Group at ScholarWorks @ Georgia State University. It has been accepted for inclusion in UWRG Working Papers by an authorized administrator of ScholarWorks @ Georgia State University. For more information, please contact scholarworks@gsu.edu. 
Working Paper 2009-4-1

April 2009

\title{
The Impact of Public Library Use on Reading, Television, and Academic Outcomes
}

\author{
Rachana Bhatt \\ Georgia State University
}




\title{
The Impact of Public Library Use on Reading, Television, and Academic Outcomes
}

\author{
Rachana Bhatt* \\ Department of Economics \\ Georgia State University \\ Revised Version: February 2009
}

\begin{abstract}
Do individuals engage in beneficial activities, like recreational reading, if the necessary materials are easily accessible and relatively inexpensive? I investigate this issue by estimating how much reading time increases as a result of public library use. To address the endogeneity of library use I use an IV approach where the instrument is a household's distance to their closest public library. Using data from the Current Population Survey, American Time Use Survey, and National Household Education Survey, I find that library use increases the amount of time an individual spends reading by approximately 26 minutes on an average day. Moreover, it increases the amount of time parents spend reading to/with young children by 12 minutes. This increase in reading is more than offset by a 58 minute decrease in time spent watching television, and there is no significant change in other activities. For children in school, library use positively impacts homework completion rates. A simple cost-benefit exercise highlights the potential application of these results for local governments who fund these libraries.
\end{abstract}

JEL Classification: I20, J01, J18

Keywords: public libraries, reading and education, leisure activities

\section{Introduction}

It is widely acknowledged that reading for pleasure is a beneficial leisure activity. While serving as a source of entertainment, reading also aids cognitive development by keep-

*I am thankful to Gordon Dahl, Uta Shönberg, Julie Cullen, and Nora Gordon for their suggestions and input, as well as the Macro/Applied Seminar participants at U of R, and Applied Seminar participants at UCSD. Additionally, I am grateful to many students at both universities for their comments and suggestions. All remaining errors are my own. Please contact the author with comments and suggestions atrbhatt@gsu.edu 
ing the mind actively engaged and training it to process and store information. The importance of recreational reading has been highlighted by educators and policy makers alike. Former U.S. Secretary of Education Richard Riley emphasized the role of reading for academic success in children: "...[reading] is extraordinarily important...Research clearly shows that the more children read and are read to the better they can read and learn all other subjects. " Regarding adult literacy, the National Governors Association has urged states to: "...emphasize the importance of adult reading for its value in lifelong learning and cultivating informed, engaged citizens. Strong reading habits enhance skills required in the $21^{\text {st }}$ century workplace, such as high literacy and analytical thinking (Bayard, 2006)." These statements are corroborated by the research on reading, which links the activity to gains in literacy achievement (improved text comprehension and writing ability), general knowledge, and reasoning and problem solving skills for both children and adults. These findings hold when important background characteristics like health, wealth, IQ, and education are controlled for, as well as in experimental settings (Elley, 1994; Clark and Rumbold, 2006; Cunningham and Stanovich, 1998; Smith, 1994; West et al., 1993). Celano and Neuman (2001) find that young children who were randomly assigned to attend a summer reading program showed higher literary comprehension levels during and after participation than their counterparts.

Despite these benefits, reading rates are low. A 2004 report by the National Endowment for the Arts finds that only $46.7 \%$ of individuals age 18 and older read at least one book over the past year (NEA, 2004). For children, $79 \%$ of 0 to 6 year olds read or are read to on a daily basis, and this percentage is smaller for children in school: $54 \%, 30 \%$, and $22 \%$ of nine, thirteen and seventeen year olds admit to reading for pleasure almost every day (Perie and Moran, 2005; Rideout et al., 2003). In terms of intensity, little time is spent on reading, as compared to time spent on other leisure activities. Figure 1 illustrates these numbers for two age groups, on the left children age 0 to 6 , and on the right individuals age 15 and older. On an average day, young children spend 39 minutes reading or being read to, compared to 103 minutes spent watching television. This ratio is magnified among adults; they read 21 minutes per day and watch television for 156 minutes (Bureau of Labor Statistics, 2007; Rideout et al., 2003). Reading is contrasted with television because the majority of leisure time is spent on the latter activity, and

\footnotetext{
${ }^{1}$ See http://www.superkids.com/aweb/pages/features/riley/seced1.html In addition, one of the long term objectives of the 2001 No Child Left Behind Act has been to ensure that every student can read at or above grade level by the end of their third grade year, and leisure reading is viewed as a key activity to build up academic reading skills. See No Child Left Behind at www.ed.gov/nclb for more information.
} 
moreover, there is a large literature which examines the negative consequences of excessive television viewership (Gentzkow, 2006; MacBeth, 1996; Olken, 2006; Robinson et al., 2001; Waldman et al., 2006). These low reading rates have been linked with poor academic achievement and job performance: Children who read infrequently for pleasure score 4 to 18 points lower on standardized reading tests compared to those who read frequently, and close to $34 \%$ of business owners rank their high school educated employees as being deficient in reading comprehension skills that are critical for job success (Conference Board, 2006; Perie and Moran, 2005).

There are a few programs in the U.S. which encourage reading by lowering the cost of the activity. ${ }^{2}$ First Book, Reach Out And Read, and Reading Is Fundamental provide free books to families with children at shelters, pediatric exam rooms, and Head Start centers. The Big Read provides the resources and infrastructure for individuals to read and discuss books with other members of their community. In follow-up surveys, participants of the First Book program reported a 55\% increase in reading interest, and parents who received books through Reach Out and Read began to read more to their children. ${ }^{3}$ Although these programs seem to have the desired impact, the results may not be generalizable outside the target population of low income households with children. More importantly, there is no quantitative estimate of exactly how much reading results from having access to low cost reading materials. This paper aims to answer this question by estimating how a more widespread source of inexpensive books-public libraries-affects reading rates among a more general population-public library users.

There are over 17,000 public libraries in the U.S. which provide books, audio and video discs, computers, internet access, and quiet study areas to hundreds of millions of visitors each year. The number of visits in 2004 alone totaled to 1.3 billion, with an average of 4.7 visits and 7.1 loaned items per capita. Public libraries are public goods that are primarily financed through local sources. Total operating expenditure for all public libraries in 2004 was close to $\$ 9.1$ billion, $82 \%$ of which was funded by local governments through property tax revenue, $11 \%$ by state and federal governments, and the remainder through grants, donations, and fines (Chute et al., 2006). Considering the source of funding, the widespread use of libraries, and the benefits attached to reading,

\footnotetext{
${ }^{2}$ In a similar fashion, participation in exercise and smoking cessation has been encouraged by altering the costs of these activities through leisure vouchers and tobacco taxes. (Carpenter and Cook, 2007; WERG, 2006).

${ }^{3}$ For more information see http://www.firstbook.org, http://www.reachoutandread.org, http://www.rif.org, and http://www.neabigread.org. The Big Read organizes kick-off programs, panel discussions, and author readings for participating communities.
} 
it is useful for educators and local governments to have an estimate of the impact of public library use on reading time. I quantify this amount, and acknowledging that increased reading time comes at the expense of other activities, as well as the fact that libraries offer a number of non-reading resources, I estimate the impact of use on various other leisure and non-leisure activities. Finally, since books, research databases, and study areas can be particularly important for children in school, I examine the impact of library use on academic outcomes.

It is difficult to estimate the causal effect of library use on reading (and other outcomes) since this activity is not randomly assigned across the population. Individuals who use the library may read more not because of library use per se, but because they have a strong (unobserved) taste for reading. Alternatively, those who like to read the most may tend to buy their books or borrow from friends instead of from public libraries. This can lead the OLS estimates to be upward or downward biased. In addition, if library use is measured with error, the OLS estimates will be attenuated. To obtain unbiased estimates in light of these issues, I use an IV approach where the instrument is the distance of each household to their closest public library. I find that close proximity to a library is strongly associated with higher rates of library use, and I provide a number of pieces of evidence suggesting that distance is a valid instrument. I focus on two concerns in particular: (i) There is not selection into library distance, and (ii) Distance does not proxy for neighborhood quality nor distance to other services and amenities.

Using merged data from the Current Population Survey and American Time Use Survey, the IV results indicate that library use in the past month significantly increases time spent on reading by roughly 26 minutes on an average day, and this crowds out time spent on watching television by 58 minutes. Moreover, among households with young children, I find that library users read close to 12 minutes more with/to household children than non-users. There is no statistically significant effect on any other activities. Finally, using the National Household Education Survey, I find that library use significantly increases the probability of homework completion and good behavior. The magnitudes of the OLS and IV estimates suggest that the OLS estimates are downward biased by the presence of measurement error and/or that individuals that like to read the most will tend not to use the public library. I provide empirical and anecdotal evidence that is consistent with both of these scenarios. Lastly, I perform a simple cost-benefit calculation that contrasts the benefit of increased reading through improved library access with the cost of doing so, and find the benefit per worker is slightly less than the associated cost. 
The remainder of the paper is organized as follows: In Section 2 I discuss the data, and in Section 3 I outline the empirical strategy, and discuss the validity of the instrument. Section 4 contains the results, and in Section 5 I discuss the relationship between IV and OLS, and provide the cost-benefit analysis. Section 6 concludes.

\section{Data}

\subsection{Current Population Survey (CPS)}

The analysis uses data from the Current Population Survey School Enrollment/Library Use Supplement that was collected in October 2002. The supplement includes the standard demographic and socioeconomic information that is collected in each CPS month: Household level information like income and state of residence, and individual level information like each household member's age, sex, and race. In addition, each household respondent was asked whether or not anyone in the household had used a public library in the past month (September-October 2002), as well as the distance of each household to their closest public library (responses were categorized in mile categories: less than 1 mile, 1-2 miles,...10 plus miles). ${ }^{4}$ Information was collected for approximately 45,000 households, and one important detail to note is that the data do not specify which member(s) of a household used the library, just whether or not it was used by someone in the household.

\subsection{American Time Use Survey 2003 and 2004 (ATUS)}

I merge the CPS data with data from the 2003 and 2004 American Time Use Survey. This is possible because starting in 2002, households in their final interview month of the CPS were sampled and chosen to participate in the ATUS. ${ }^{5}$ Within each of these households, one individual (age 15 and up) was randomly selected to provide information about his/her activities over a randomly assigned day. Respondents were asked to describe each activity they did, how much time (in minutes) they spent on the activity, and if applicable, who else was present during the activity. Since only a

\footnotetext{
${ }^{4}$ CPS administrators designate one person in each household to be the respondent for that household. $\mathrm{He} / \mathrm{she}$ is in charge of answering the questions asked about the household as well as providing information for any individual level questions about members. Typically the respondent is the homeowner, but any household member above the age of 15 is eligible to be the respondent.

${ }^{5}$ Households in the CPS are interviewed once a month for four months, are out of the CPS rotation for eight months, and then are surveyed for another four months. The "final" month is the last month of the second set of four months.
} 
portion of the households in the October 2002 Supplement were sampled for the ATUS, the final merged data set consists of over 8,000 households with library and time use information. ${ }^{6}$

The merged data have three noteworthy points. First, the horizon for library use is over a month, while time-use activities are measured over a particular 24 hour period. As a result, the estimates measure how the resources obtained from (or used at) a library affect the day-to-day activities of an individual, and not how library use on a particular day affects that same day's activities. This is an empirically relevant question since the majority of library patrons ( $88 \%$ in the CPS data) visit the library to check out books and use them outside the library for an extended period of time (typical loan length is 3-4 weeks). ${ }^{7}$ Second, this 24 hour diary period does not fall within the month that library use was measured. There is a substantial lag between October 2002 and the diary date (anywhere from 3 months to a year and a half later) owing to the nature of the CPS rotation and ATUS diary date assignment. ${ }^{8}$ I assume that each household's library use during September-October 2002 is representative of their behavior in any given month, hence use (non-use) during this month implies use (non-use) during the diary month. Finally, library use is measured at the household level, while time use is only known for one individual in the household. In the best case scenario, the measure of library use reflects the actions of the ATUS respondent, and hence a "direct" effect of library use is estimated. However, there may be observations where someone in the household used the library, but it wasn't the ATUS respondent. I assume that the estimates will, at the very least, pick up any "spill-over" effects that may accrue to the ATUS respondent from living in a house where there are library users. These users likely expose other household members to library resources by bringing home books and other materials,

\footnotetext{
${ }^{6}$ I exclude military, group-quarter and non-English speaking households, households with missing information on income, and households where the ATUS respondent did not live in the household during the October 2002 interview. In addition, I make the restriction listed in Footnote 9 (age of CPS respondent). This leads to a final sample size of $\mathrm{N}=8,332$.

${ }^{7}$ In the CPS data, households were asked what they used the library for, conditional on having used the library in the past month. Responses include the following non-mutually exclusive activities and participation rates: Use computer and internet $(28 \%)$, attend program or meeting $(24 \%)$, school assignment (35\%), find a job (5\%), work assignment (8\%), find information on consumer and financial issues $(28 \%)$, enjoyment and hobbies $(65 \%)$, use internet outside the library to access library resources $(24 \%)$.

${ }^{8}$ For those households that were in the last four months of their CPS rotation during October 2002, their time use data was collected in 2003. For households that were only in their first four months, their time data was collected in 2004. 5,128 observations come from ATUS 2003, and 3,204 come from ATUS 2004. Once the household and specific respondent were selected during the final CPS month, the ATUS diary date was assigned for 3 to 5 months in the future.
} 
and this can alter how the diary respondent spends his/her time. I discuss how these data nuances may affect the results in Section $5 .^{9}$

\subsection{National Household Education Survey (NHES)}

The third data set used in this research is the National Household Education Survey collected by the National Center for Education Statistics. This survey was administered in 1996 to over 15,000 households with children enrolled in elementary and secondary school. It includes information on the demographic, socioeconomic, and geographic characteristics of the household, as well as whether or not anyone in the household used the library in the month prior to the survey (like the CPS, the specific user(s) is not identified), and the household's distance to the library (coded in mile categories). In addition, the survey collects information about children's school experience such as misbehavior problems, average grades, homework completion, and grade retention. ${ }^{10}$ I estimate the impact of library use on these educational outcomes, but can not identify which specific library resources drive the results. For instance, it could be that academic outcomes improve because children have greater practice with reading, or because they benefit from having a quiet study space to concentrate and do work. Again, I assume this monthly measure reflects typical behavior of the household, and that there can be spill-over effects on the child in the cases when they are not the actual library users.

\section{Empirical Methodology and Identification}

\subsection{Empirical Methodology}

The OLS estimate of the impact of library use on reading is estimated from the following equation: $y_{i}=\beta_{1}+\beta_{2} \times l_{i}+\beta_{3} \times x_{i}+\epsilon_{i}$. $y_{i}$ measures the total time (in hours) that individual $i$ spends reading for pleasure on the diary day, $l_{i}$ is an indicator for whether or not someone in $i$ 's household used the library in the past $\operatorname{month}(=0$ no, $=1$ yes $)$, $x_{i}$ is a set of observed characteristics, and $\epsilon_{i}$ is the error term. In addition, I estimate the equation when the dependent variable is hours spent on other leisure and nonleisure activities and binary academic outcomes. For regressions using the CPS-ATUS data, $x_{i}$ includes household level variables like income, number of household members,

\footnotetext{
${ }^{9} \mathrm{~A}$ final concern is that for some households, the CPS respondent may just not know whether anyone in the household used the library. To improve the accuracy of the responses, I restrict the sample to those households where the CPS respondent was greater than 18 years old. This excludes 81 households, and results do not qualitatively change if these households are included in the estimation.

${ }^{10}$ Outcomes like standardized test score performance were not collected.
} 
and the average demographic characteristics of members (i.e. fraction of females in the household, fraction under the age of 15 , etc...); geographic information like urban status, MSA size, and state fixed effects; individual demographic controls for both the CPS and ATUS respondent (i.e. age, sex, race, education, employment status); and interview date characteristics like day, month and year. ${ }^{11}$ For regressions using the NHES data, $x_{i}$ includes similar household and geographic controls (including state fixed effects), as well as controls for the child whose outcomes are examined (i.e. age, sex, race, grade.) ${ }^{12}$ In all regressions, I cluster standard errors by state of residence.

The OLS estimates will be biased if there is non-random selection into library use, and the direction of the bias depends on the sign of the covariance between library use and the unobserved heterogeneity. ${ }^{13}$ For instance, the OLS estimates for reading will be upward biased if those individuals that like to read (unobserved) also tend to use the library. Although this may seem like the intuitive direction of selection, it could be that those who like to read the most don't use the public library, and instead buy books or borrow from friends. This will lead to OLS estimates that are downward biased. ${ }^{14}$ In addition, the OLS estimates will be attenuated if there is measurement error in library use. A priori, there are a few reasons why this may occur in the CPS-ATUS and NHES data. First, both surveys asks respondents to recall what happened in the past month, and there may be some people who just don't remember. Second, household library use is an imperfect (nosisy) measure of what the actual ATUS individual does and is exposed to. Finally, the one-month snapshot of library use may just be atypical of the household's behavior and hence not indicative of use in the ATUS diary month. In Section 5 I investigate whether and to what extent these sources of error affect the OLS results, as well as the type of selection suggested by the estimates.

\footnotetext{
${ }^{11}$ I include CPS respondent characteristics to control for the knowledgeability of the CPS respondent regarding library use by the household. For instance, a stay at home mom is more likely to know if a household child used the library, compared to fathers who are employed full-time. I draw information on library use, distance, socioeconomic, demographic, and geographic characteristics of the household and CPS respondent from the CPS Supplement, and information on time activities, characteristics of the ATUS respondent and relevant interview information from the ATUS data.

${ }^{12}$ The NHES respondent is not identified, so controls for this person cannot be included in the regressions. A list of the CPS-ATUS and NHES regressors are available upon request.

${ }^{13}$ More formally, let $\epsilon_{i}=\alpha_{i}+\mu_{i}$, where $\alpha_{i}$ is the unobserved characteristic and $\mu_{i}$ is an idiosyncratic disturbance. The OLS estimate of library use is $\hat{\beta}_{2}=\beta_{2}+\frac{\operatorname{cov}\left(\alpha_{i}, \tilde{l_{i}}\right)}{\operatorname{var}\left(\tilde{l}_{i}\right)}$, where $\tilde{l}_{i}$ is the residual from the regression of library use on observed characteristics $x_{i}$. The direction of the bias depends on the sign of $\operatorname{cov}\left(\alpha_{i}, \tilde{l}_{i}\right)$.

${ }^{14}$ The presumed endogeneity of library use is reinforced by two studies in economics which use the presence of a household library card as a proxy for unobserved ability (Betts, 1995; Farber and Gibbons, 1996).
} 
The IV estimator produces results that are unbiased in the presence of unobserved heterogeneity and measurement error. In the first stage, library use is regressed on the household's distance to the library (denoted $d_{i}$ ) and other observed characteristics: $l_{i}=\gamma_{1}+\gamma_{2} \times d_{i}+\gamma_{3} \times x_{i}+\eta_{i}$. The predicted value, $\hat{l}_{i}$ is used in the second stage outcome equation: $y_{i}=\beta_{1}+\beta_{2} \times \hat{l}_{i}+\beta_{3} \times x_{i}+\epsilon_{i}$. The IV estimates will, under the assumptions of monotonicity and independence, capture the average treatment effect for those individuals who are induced to use the library because of distance-the compliers (Imbens and Angrist, 1994). ${ }^{15}$ The IV estimates are unbiased provided that distance is correlated with library use, but uncorrelated with any unobserved factors that affect the outcome. The following sections explore the strength of these conditions.

\subsection{First Stage IV Results}

Prior to presenting the first stage results, it is worthwhile to consider why distance may affect library use. Presumably, living close by lowers the time and transportation costs of a visit, essentially making it a more convenient activity. Consequently, households living farther from a library are less likely to go than those living close by. Indeed, raw statistics from the CPS data show use is higher among closer dwelling households: $44 \%$ of the households living less than 1 mile from their closest public library went to the library in the month prior to the survey, and this percentage monotonically decreases as distance increases: $41 \%, 38 \%, 29 \%$, and $24 \%$ of households living 1 to 2,3 to 5,6 to 10, and 10 plus miles away respectively, used the library. ${ }^{16}$ Table 1 displays the results from the first stage regression using the CPS-ATUS data. I estimate the equation using a linear probability model where library use is a binary variable, and distance to the library is separated into five dummy categories (a probit model yields similar results). The coefficients on the distance categories are presented in the table, with omitted category living less than 1 mile away. The first column presents the results using all 8,332 households. The final three columns are restricted to just households that have children of given age levels (these are not mutually exclusive).

Consider the estimates for all households for illustration. The coefficients indicate that there is a strong negative relationship between library use and distance to the library. There are $3.7 \%$ fewer library users among households living 1 to 2 miles away

\footnotetext{
${ }^{15}$ The effect of treatment for compliers, called the local average treatment effect, is representative for the entire treated population if there is a constant treatment effect.

${ }^{16} 1,824$ households live less than 1 mile away, $\mathrm{N}=2,487,2,546,953$, and 522 for households living 1 to 2,3 to 5,6 to 10 , and 10 plus miles away. The number of households that visited the library in the month prior to the survey is 3,248 out of 8,332 households.
} 
than there are among households living less than 1 mile away. The percentage of library users strictly decreases with distance, at 10 plus miles there are $16 \%$ fewer households who visit the library. The F-statistic testing the joint significance of the instrument is $26.59[\mathrm{p}$-value $=0.0000]$ and reported at the bottom of the column. This is large enough to fail to accept the null hypothesis of joint insignificance. All remaining columns exhibit this same strictly decreasing probability of library use as distance increases, however the point estimates are generally larger (in absolute value) among households with children. This implies that distance is a larger deterrent for households with kids. I attribute this to the extra time and exertion required to coordinate a library visit if children are involved. The first stage IV estimates using the NHES data are presented in Table $2 .{ }^{17}$ The first column presents the results from all 15,511 households, while the remaining columns split the sample by urban status. The estimates in all columns show the same pattern of decreased library use as distance increases as seen in Table 1. The separation by urban status will be useful when discussing the results in Section 4 .

The monotonicity condition assumes that there are no defiers: I.e. There are no households that would use the library if they lived far away, but wouldn't use it if they lived close by. ${ }^{18}$ I attempt to verify this by predicting each household's library use based on all observed characteristics less distance, defining quartiles of predicted library use, and comparing households' actual library use, by distance, within these quartiles. The same pattern emerges within each quartile: There is a larger fraction of library users among households that live near a library as compared to the fraction of users who live farther away. This suggests that regardless of whether a household has a high or low predicted probability of use, further distance always seems to discourage the likelihood of using the library. ${ }^{19}$

\footnotetext{
${ }^{17}$ The number of library users in the NHES data is 4,598 out of 15,511 households.

${ }^{18}$ This leaves the following compliance types (by treatment status and instrument value): compliers (use the library if they live near by, don't use the library if they live far away), always-takers (regardless of distance use the library) and never-takers (regardless of distance never use the library).

${ }^{19}$ For instance, among those households that have the lowest predicted probability of library use, the fraction of actual users by distance is: Less than 1 mile away (0.19), 1 to 2 miles (0.15), 3 to 5 miles (0.11), 6 to 10 miles (0.09), and 10 plus miles (0.10). Moreover, the fraction of library users is consistently higher among households living the same distance from the library across quartiles: For households living less than 1 mile from the library: 1st Quartile (0.19), 2nd Quartile (0.31), 3rd Quartile (0.51), 4th Quartile (0.74). Results available upon request.
} 


\subsection{Validity of the Instrument}

\subsubsection{Selection into Distance}

One concern with using distance as an instrument is that there may be selection into distance. Households choose where to live, so it may be that households that value reading or emphasize strong study habits for children will systematically choose to live closer to a library because they plan to use it often. This will bias the IV estimates, making it impossible to isolate the causal effect of library use. It is not possible to directly observe whether households behave this way, but there are a few indirect ways to gauge if selection into distance occurs.

First, it is possible to assess whether households living different distances from the library substantially differ in characteristics that reveal their preferences for reading. These include a household's non-public library use (i.e. research, work, and school libraries), cable/satelite television subscription status, and rules regarding television viewership for young children. For instance, if households that like to read use public and non-public libraries (assuming they are complements) and choose to live close to a public library, then there will be a larger fraction of non-public library users among households living close to the public library than among those living farther away. ${ }^{20}$ The first row of Table 3 displays the fraction of households at each distance from the public library that used the non-public library in the month between September-October 2002. As can be seen, the fractions fluctuate only a little between 0.36 and 0.4 , and more importantly, they do not exhibit any systematic pattern. This is reinforced by the small F-statistic on a test of the joint significance of the distance dummies when non-public library use is regressed on distance to the public library and other controls. In the second and third rows, the fractions of households with cable/satelite television, and households where parents have rules regarding how much television their children can watch are given. If a household values reading, they may prefer it to other leisure activities like watching television, and so are less likely to purchase cable/satelite services, and are more likely to restrict children's viewership. As with non-public library use, the fractions of households with these characteristics is similar across distance. The statistics suggest that households that seemingly value reading and academic outcomes-as inferred by their non-public library use and perceptions about television-are no more likely to live

\footnotetext{
${ }^{20}$ If public and non-public libraries are substitutes for one another and there is selection into distance, then presumably non-public library use will be lower among households that live close to a public library. However, this is not a straightforward prediction, since we also expect those living farther away to not only use the public library less but also use the non-public library less.
} 
close to a library than those that don't. ${ }^{21}$

A second approach is to look at a household's past history of library use and the distance they currently live (the residence of the CPS October 2002 Library Supplement) from the library . If there is selection into distance, then it's likely that households that have used the library in the past-and presumably plan to use it in the future-will choose to live close to a library when they move to a new location. This can be assessed using information on households' residential history and library use in the year prior to October 2002. In the October Supplement, households were asked whether or not anyone had used the library in the past month (September-October 2002). Those that answered no were then asked whether or not anyone had used the library in the past year (September 2001-2002). Residential history is obtained by merging the October 2002 Supplement with data from the November 2002 Supplement, which asks households how long they have lived at their current residence. This combined information reveals how long a household lived in the residence that their October 2002 survey was conducted at, and whether they used the library in the past year. For those that recently moved to their current residence, their past year's use reveals information about their library use at their previous residence. ${ }^{22}$ Consequently, it's possible to determine whether those households that used the library prior to moving chose to live close to a library when they moved.

Table 4 displays the results. For each distance category, I calculate the fraction of households that used the library in the month prior to the survey, and the fraction that used the library in the year prior to the survey. This is done for two populations: Households that moved into their current residence zero to five months prior to October 2002 (hereafter, new residents), and households that moved to their current residence one to two years prior to October 2002 (hereafter, old residents). ${ }^{23}$. The left hand side of Table 4 (columns (i) and (ii)) displays the results for library use in the past month

\footnotetext{
${ }^{21}$ Households in the CPS 2002 Supplement were asked about their non-public library use in the past month. They were not asked how far they live from these non-public libraries, however. Data on cable/satelite subscription information was obtained from the CPS October 2003 Supplement. Not all households from CPS Ocotber 2002 were in the October 2003 interview, hence the smaller sample size. Data on rules for children's television viewing were taken from the NHES data, and moreover, this question was only asked in households with young children.

${ }^{22}$ Note that no information is available about how far a household lived from the library at their previous residence.

${ }^{23}$ The comparison group-old residents-was purposely constructed from a group of movers, instead of say, households that had moved 5 years prior or never at all, to alleviate concerns that the results for new residents are due to the select nature of movers. The November 2002 Supplement categorizes residential history, so it is not possible to tell if a household moved 1,2,3,4, or 5 months prior to October 2002 , only that they moved 0 to 5 months prior.
} 
for new and old residents, respectively. The far left hand side of these columns, (i-a) and (ii-a), displays the fractions of households, and in (i-b) and (ii-b) are the coefficient estimates when past month library use is regressed on distance and other controls. The result is the same for both groups: The probability of library use decreases monotonically as distance increases. This is expected, since both of these groups lived at their current residence in the month prior to the survey, and distance naturally affects their library use. Columns (iii) and (iv) display the fractions and regression coefficients for library use in the past year. Unlike the left side of the table, only the old residents display a decreasing probability of use by distance. For this group, library use in the past year reflects their actions at their current residence, since these households moved at least 1 year prior to the survey. In contrast, there is almost no difference in use by distance for the new residents, suggesting their past use is unrelated to how far they currently live from the library. For them, past year use mostly refers to their behavior at their prior residence, since at most, they moved 5 months prior to the survey. ${ }^{24}$ These estimates indicate that those households that used the library prior to moving are no more likely to move close to a library when they move, and this suggests that systematic selection into distance does not occur.

\subsubsection{Location of Libraries}

An additional concern regarding library location is that libraries are only located in "high quality" neighborhoods. In this case, households that live close to a library by default live in neighborhoods with high average education levels, high income, etc... Although all regressions control for these observed characteristics, there may be some unobserved characteristics that are correlated with distance and hence confound the IV estimates. Property value is one common measure of neighborhood quality, but this information is not available in the CPS-ATUS nor NHES data. What exists however, is information regarding the quality of schools that households send their children to, and school quality is highly positively correlated with property value. The lower half of Table 3 displays the fraction of households-by distance-where a child attends a public school, receives a free or reduced price lunch, or has access to computers at school. Public school attendance reflects the quality of the school district (assuming the alternative to a bad public school

\footnotetext{
${ }^{24}$ The negative coefficient estimates for 6 to 10 and 10 plus miles in Column (iii-b) suggest that there are fewer households that used the library in the past year that chose to live in these locations, but the differences are not statistically significant and are small in magnitude. These results could stem from households whose response to past year library use was based on their library use at their current residence.
} 
is private school), free lunch recipients reflect the income levels of children at these schools, and computers reflect the type of available resources. ${ }^{25}$ The fractions and size of the F-statistics suggest a similar conclusion as the upper half of the table: There are not systematic differences in school-and hence, neighborhood quality-by distance to the library, indicating that libraries are not strictly located in better quality neighborhoods. The results of this exercise address an additional concern regarding distance: Since children are sent to schools based on proximity to their residence, parents who want to ensure their child receives a good quality education will select to live in areas with better schools. If higher quality schools are systematically located in neighborhoods with libraries, the IV estimates for academic outcomes will be biased. However, the estimates in Table 3 suggest this is not an issue.

There may be some concern that distance measures not only how far a household lives from the library, but also how far the household lives from other amenities and services. For instance, if libraries are located close to bookstores, shopping malls, community centers, or other recreational services, then the IV estimates may capture the effect that these non-library services have on outcomes. Using data from the 2001 National Household Transportation Survey, which details the travel behavior of U.S. households, I calculate the correlation between the distance a household travels to get to a public library, and the distance they travel to get to various recreational services. The magnitudes of these correlations are small and range anywhere from -0.19 to 0.10, suggesting that there's little reason to suspect that library distance proxies for distance to other services. ${ }^{26}$ With regards to library placement, McCarthy (2007) finds that local and state governments vary in where they allow public libraries to be placed: While some

\footnotetext{
${ }^{25}$ The information about public school attendance, free lunch recipients, and computers at school were taken from the October 2002, December 2002, and October 2003 CPS supplements, and then merged with data from the October 2002 Library Use supplement. Since not all October 2002 households were in these other surveys, the sample size differs.

${ }^{26}$ The National Household Transportation Survey records the travel behavior of a representative sample of households in the U.S. Households detail their travel destinations (where from and where to) and durations (distance in miles, time in minutes) during a randomly assigned travel day. I use information from the survey to calculate the distance from a household's residence to the library (this information is only available if a household visited a library on the travel day), and from the residence to locations where the household could shop, run errands, buy goods and services, exercise, engage in socializing and recreational activities, purchase meals, and visit medical/dental/legal professionals (again, this information is only available if a household engaged in these types of activities on the travel day). The correlations between library distance and distance to these other services are: Medical/dental/legal services (0.10; N=17), Shop/Errands (0.026; N=29), Buy Goods (-0.06; N=62), Buy Services (-0.13; $\mathrm{N}=40)$, Socialize/Recreational $(-0.19 ; \mathrm{N}=9)$, Gym/Exercise $(0.10 ; \mathrm{N}=49)$, Meals $(0.01 ; \mathrm{N}=55)$. The small sample sizes are due to the fact that correlations can only be calculated if the household traveled to the library and performed these other services on the same day. Results are available upon request.
} 
governments allow libraries to open in residentially zoned areas, others only permit them in business areas. This suggests there is no uniform placement of libraries close to other amenities. $^{27}$ On a related note, there is no indication that households living various distances from the library have differential access to amenities and services which may affect their time use and academic outcomes directly. Conditional on library use, the same fraction of households living less than 1 mile away as living 10 miles away use the library for school work $(35 \%)$ or to use the computer and internet $(28 \%)$. This implies that households that live far from a library are not more likely to use the library for school work or internet because they lack access to after school centers or internet near their home. This is also evident in Table 3: Households living different distances away from the library have similar cable/satelite television subscription rates, and this hints at having similar access to service providers. Consequently, any differences in outcomes by distance are not due to differences in non-library resources by distance. ${ }^{28}$

\section{Results}

\subsection{Reading and Time Use Activities}

The OLS and IV estimates of library use on various time activities are only statistically significant for two activities: Time spent reading for pleasure and watching television. These estimates are given in Table 5, and the remaining leisure and non-leisure activities are displayed in Table 6 . Since the reading and television estimates are of particular interest, I focus the discussion there first. The upper half of the table displays the estimates for all households, where the dependent variable is the number of hours the ATUS respondent spent reading or watching television on the diary day. The remainder of the table is restricted to just households with children. Here the dependent variable is the number of hours that ATUS respondents who are parents spent reading to/with a child, or watching television with a child present in the room. ${ }^{29}$ The OLS estimates are

\footnotetext{
${ }^{27}$ In addition, anecdotal evidence suggests that it has become a recent but irregular trend to place public libraries inside of shopping malls. These mall libraries are generally small-scale and offer limited service, and are placed in malls to entice patrons to then visit full-service community libraries (Forsyth, 2006; McMichael, 2004). The placement of these quick-service libraries inside malls suggests that fullscale libraries are not located nearby.

${ }^{28}$ The alternative activities performed at the library are listed in Footnote 7 . Like school work and computer use, conditional on use, the fraction of households that use the library for any of these other purposes does not differ by distance. Results available upon request.

${ }^{29}$ I focus on time spent between parents and children since parents bear the primary responsibility for care giving. Sample size for these estimations are: 0 to 5 years old $(\mathrm{N}=1,600), 6$ to 12 years old $(\mathrm{N}=1,953), 13$ to 18 years old $(\mathrm{N}=1,171)$. Results do not qualitatively change if all ATUS respondents
} 
presented in the first column, IV in the second, and the third displays the unconditional means for time spent on these activities. All the point estimates are in hours; minute equivalents are obtained by multiplying the coefficients by 60 .

The OLS estimates indicate that an individual who lives in a household that used the library in the past month reads 9 more minutes per day and watches 12 fewer minutes of television, than if he/she did not. When library use is instrumented, these results do not diminish, but rather increase in magnitude (in absolute value): Library users read roughly 26 minutes more per day than non-users, and watch 58 minutes less television. Since the IV estimator only uses a limited amount of information, the estimates are less precise, but the results are still statistically significant. Compared to the average in the population, library users read an equal amount more and watch a third less television. For households with children age 0 to 5 , the IV estimates indicate a 12 minute increase in reading to/with a child. There is no significant effect for reading with older children nor watching television with children of any age level. ${ }^{30}$

The magnitude of the IV reading estimates are large but consistent with the findings of observational studies. For instance, Neuman and Dickinson (2005) find that the average ratio of (owned) books per child in high-income neighborhoods is 13:1, while it is 1 age-appropriate book for every 300 children in low-income neighborhoods. Consequently, low-income children are potentially exposed to an average of 25 hours of reading per year, while high-income children are exposed to 1,000 hours per year. This suggests that exposure and access alone can have a powerful effect on reading rates. The estimated 26 minute increase in reading per day translates to reading 13 more hours per month. Given average reading speeds and book lengths, this is equivalent to reading 1 paperback book, 20 newspaper articles, and 12 magazine articles over a month. ${ }^{31}$ This amount of reading is consistent with anecdotal evidence on the number of items checked out per library visit and standard loan lengths: Griffiths et al's. (2004) survey of Florida public library patrons indicates that conditional on use, $80 \%$ of library visitors check out 2 or more items per visit, and keep items for 3 to 4 weeks at a time.

The television finding is slightly less straightforward, but still intuitive. Public libraries provide resources like VHS and DVD tapes, which if utilized, may increase the

(i.e. brothers, sisters, grandparents, other relatives are included.

${ }^{30}$ The imprecise estimates for watching television are likely due to the fact that this activity can only indirectly be measured in the ATUS data. No separate activity code exists for watching television with a child, so I infer this by calculating time spent watching television with a child present in the room.

${ }^{31}$ The estimates are based on the following statistics: average reading rate: 250 words/minute, length of paperback novel: 80,000 words, newspaper article: 3,000 words, magazine article: 5,000 words (Brogan and Brewer, 2003). Equivalently, an individual could read 2.5 paperback novels over a month. 
amount of time an individual spends watching television. ${ }^{32}$ However, the IV estimate suggests library use actually decreases television time, and logically this is because it is crowded out in favor of increased reading. In order to maintain an increase in one activity, it is necessary to cut out other activities, and it is not surprising to find that one sedentary leisure activity is substituted for another. Moreover, it is the leisure activity that the most time is spent on. It is important to note that the results of Table 3 comparing cable/satelite subscription rates and television rules suggests that the IV estimate is not the result of inherent differences in households' attitudes towards watching television by distance. The displacement of television is an interesting finding in light of the substantial number of studies examining the impact of excessive television viewership. Olken (2006) finds the introduction of radio and television into Indonesian villages results in lower levels of social participation, Waldman et al. (2006) find a positive relationship between television time and autism, and a number of others find mixed results when looking at the link between television and academic achievement (Gentzkow et al., 2006; MacBeth et al., 1996).

Table 6 presents the OLS and IV estimates for other leisure and non-leisure activities. The only significant OLS estimate is for volunteering, but the IV estimate for this and other activities are not significantly different from zero. Some of the point estimates are non-zero, and this is consistent with the findings of Table 5. The estimated decrease in television time more than offsets the increase in reading, so from an accounting standpoint, time spent on other activities must necessarily shift. Moreover, libraries offer a number of non-reading resources like computers, internet, child and adult programs that can directly affect these other activities. For instance, in the CPS data, close to $28 \%$ of library users used the library to do personal research on consumer, health and financial information. The non-zero IV estimate for research shopping and financial management (i.e. comparison shopping, balancing checkbook, paying bills) may reflect a shift away from performing these activities in person and instead doing them online during a library visit. Recent reports have even highlighted the increased use of libraries to search for jobs, especially during economic downturns. Although the sample size of the unemployed population in the data is small, the direction of the estimate itself suggests increased job search (Carlton, 2009). Local governments may be particularly interested in subsidizing internet and computer placement in public libraries if it aids the local labor force in their job searches. None of the IV estimates for the activities in Table 6

\footnotetext{
${ }^{32}$ ATUS classification of television time includes actual television viewership as well as watching VHS or DVD tapes on a television.
} 
exhibit the magnitude and significance of the results in Table 5, indicating that library use primarily affects reading and television time. ${ }^{33}$

\subsection{Academic Outcomes}

Library resources can be particularly important for children in school since they provide books, reading programs, research databases, computer access, and quiet study areas to do homework. Using the NHES data I examine whether library use affects four educational outcomes for primary and secondary school children: average grades, homework completion, behavioral outcomes, and grade repetition. Each outcome is formulated as a binary variable, and the OLS and IV results are given in Table 7 . The first two sets of columns display the results separately for urban/suburban and rural households, and the final set shows the estimates from the entire sample of households. Consider the urban/suburban results first. The IV estimates indicate that library use is associated with a $17 \%$ increase in the probability of a child doing homework one more time per week, and an almost equal decrease in the probability of misbehavior. It is not obvious why misbehavior decreases; one explanation could be that library use increases a child's recreational reading and crowds out television. Consequently, children are exposed to less television violence, which previous research has suggested is correlated with high rates of aggression (Robinson et al., 2001).

The rural estimates don't display similar magnitudes (or even signs) as the urban/suburban estimates. When the data is aggregated (with controls for urban status), the effects are diminished but still present. What can account for these differences? In the first stage regressions presented in Table 2, households seem to respond in a similar manner to distance regardless of urban status. This suggests there are not geographicspecific barriers, like a lack of public transportation in rural areas, that impedes use. One explanation for the results could be that there are differences in the libraries themselves by urban status. In the NHES data, conditional on use, $11 \%$ of the rural households visited a bookmobile, in contrast to $6 \%$ of urban/suburban library users. If library use improves academic outcomes by giving children a place to do homework and access reference information, then these resources will typically only be available at stationary libraries. Finally, operating hours in suburban/urban and rural libraries in 1996 were quite different. $54 \%$ of all rural libraries were open 30 or fewer hours per week, while only

\footnotetext{
${ }^{33}$ I also estimate the impact of library use on other activities that parents perform with children (among households with children) such as playing or feeding kids, and find no effect. Results available upon request.
} 
$16 \%$ of urban/suburban libraries had these limited hours (Chute and Kroe, 1999). These differences might explain why the second stage estimates in the NHES differ according to geographic region. ${ }^{34}$

\section{Disussion}

\subsection{Selection}

One aspect of the results that warrants further investigation is the relationship between the OLS and IV estimates. OLS suggests library use increases time spent on reading by 9 minutes, but the IV estimate suggests an increase of 26 minutes. This is contrary to what we expect to find if we assume that people who have a taste for reading are more likely to use the public library. The higher IV estimate suggests the opposite selection pattern exists-those that have the greatest taste for reading don't use the library. This is a plausible scenario considering there are many other sources of reading materials such as bookstores, borrowing from friends, non-public libraries, etc... An avid reader may choose to buy books from a bookstore because he/she prefers to keep them, or because he/she prefers to get a book soon after it's published (libraries often have long waiting lists for popular books). Neither the CPS-ATUS nor NHES data contains information on book purchasing behavior, so this cannot be examined directly. However, statistics from the DDB Needham Life Style Survey, a nationally representative survey measuring social indicators in the U.S., suggests that purchasing books is a popular alternative to borrowing from the library. More importantly, avid readers tend to purchase books more than they borrow them. In the data, $70 \%$ of readers used the library to obtain books, while $90 \%$ of readers purchased their books. Comparing the behavior of light and heavy readers, $67 \%$ of heavy readers regularly purchase their books versus $47 \%$ that regularly borrow books from the library. Among light readers, 17\% regularly purchase their books and $14 \%$ regularly use the library. ${ }^{35}$ Although book purchases are the more popular option among both groups, the discrepancy is more pronounced among the former, suggesting that frequent readers use non-library sources more heavily. This type

\footnotetext{
${ }^{34}$ No substantial differences were found when urban and suburban observations were separately estimated, so I group them together.

${ }^{35}$ The term reader refers to any individual who read a book in the past 12 months. Light reader is a reader who read 1-8 books over a 12 month period, heavy is 9 or more books. Regularly purchase or visit refers to 9 or more visits to the library or purchases from the bookstore over the same 12 month period. This data was used in the book Bowling Alone: The Collapse And Revival Of American Community by Robert D. Putnam, and was accessed from: http://www.bowlingalone.com/data.htm
} 
of selection can lead to a downward biased OLS estimate, and higher IV estimate when the bias is corrected for.

\subsection{Measurement Error}

A second reason for why the OLS estimates are smaller than IV is the presence of classical measurement error in library use. ${ }^{36}$ There are three reasons to suspect library use is measured with error. First, the CPS and NHES surveys are both retrospective, so it's possible that respondents may not remember if anyone used the library. Second, library use is measured at the household level, while the time use information and academic outcomes are only known for a single individual in the household. If the library respondent reports that someone used the library, it may or may not have been the ATUS respondent or child. Although I assume there are potential spill-over effects, the household measure should be viewed as an informative, but noisy measure of the ATUS respondent/child's actual use. A third issue stems from the fact that library use was only measured over a one month period, and it's possible that this behavior was simply atypical.

Below I investigate whether the first two sources of measurement error affect the results. Micro-data does not exist to address the third source, although a few pieces of anecdotal evidence suggest that the monthly measure is representative of households' general behavior. First, the CPS Supplement was asked in October 2002, which is after the beginning of the academic year (August) for most schools. It is unlikely then that the responses are biased by households with children that are more likely to engage in heavy library use at the beginning of the school year. ${ }^{37}$ Second, in the CPS data, only $32 \%$ of households that did not use the library in the month prior to the survey used the library in the entire year before. ${ }^{38}$ This suggest that a substantial number of the households are consistent in their non-use throughout not just the past month, but also past year. Finally, in a survey of library patrons in Florida, Griffiths et al. (2004) find that close to $56 \%$ of patrons visit the library more than 5 times per year, which averages to at least one visit every two months.

The extent of measurement error due to poor recall can be assessed using data

\footnotetext{
${ }^{36}$ Note that measurement error in the instrument will not bias the IV estimates. I assume any measurement error is classical.

${ }^{37}$ The NHES data was collected in the spring of 1996, but no more detailed information than that is available.

${ }^{38}$ Of the 8,332 households, 5,084 did not use the library in the month prior to the survey. 1,647 of these households used the library in the year prior.
} 
from the CPS. After the household respondent was asked whether or not anyone in the household used the library in the past month, they were then asked to reconsider their answer and re-respond. ${ }^{39}$ Fifty-two households that initially said no changed their answer to yes the second time, and no households who initially said yes changed their answer to no. I construct two measures of use from the responses: The first measure reflects the household's first answer, and the second measure takes into account any changes that were revealed by the second response. In the upper-half of Table 8 I present the OLS estimates for reading using each of these measures. The estimates are closer to zero when the first, presumably noisier response is used, and this is consistent with the predictions of measurement error theory. Throughout the analysis, I have used the second measure as the independent variable, but this exercise highlights the idea that if the observed response is still measured with error, the OLS estimates are biased toward zero.

Finally, to examine the extent to which the household's library behavior does not reflect the actions of the individual whose outcomes are being studied, I split the 8,332 households in the CPS-ATUS into two groups. The first group contains only individuals where the CPS respondent was the same person as the ATUS respondent (hereafter, same-respondent), and the second group is composed of people where this is not true (hereafter, different-respondent). Presumably, there is less measurement error in the same-respondent group compared to the different-respondent group, since each CPS respondent, at the very least, can answer the library use question based on his/her own behavior. This implies that the household library measure in the same-respondent group is a better indicator of the ATUS respondent's actions. The lower half of Table 8 displays the OLS estimates for reading for each of these groups. As can be seen, the estimates from the same-respondent sample are larger than the different-respondent sample. These results are in line with the predictions of measurement error theory, and suggests the OLS estimates are likely downward biased by the imperfect measure of individual library use.

\subsection{Cost-Benefit Analysis}

The results of this study can be useful to the policy makers and local governments that determine funding for public libraries. The impact of library use is quantified in terms

\footnotetext{
${ }^{39}$ In the CPS, households were first asked: "In the past month, has any member of your household used a public library or bookmobile for any reason?" Immediately after they were asked: "How about to borrow materials, take a class, to use the computers, or for activities for children?"
} 
of recreational reading, and this activity can impact academic and job performance through cognitive development and analytical skill formation. To highlight this link, I perform a simple cost-benefit analysis that compares the costs and benefits of increasing reading rates through public library use. The first stage IV estimates suggests a natural way to increase library use and hence reading: Make the library more convenient to visit by reducing the distance between a household and the library. To calculate the costs of reducing travel distance, I make a number of crude simplifying assumptions. First, I consider the costs of halving the distance between a household and the library, and assume that this could be accomplished by doubling the number of libraries per square foot in a given area. Second, I look at the costs and tax payments for Monroe County, New York because information on the necessary construction costs and taxes are readily available. Currently, homeowners in this area pay approximately $\$ 98$ in property taxes each year to support libraries. Doubling the number of libraries would presumably double this tax amount, plus the costs of constructing the new libraries has to be incurred. The average cost for a new library in this county is $\$ 6$ million, which spread out over a 20 year period (typical length of a levy or bond) is $\$ 33$ a year. These numbers imply a property tax-payer cost of $\$ 230$ per year for twenty years, and then $\$ 197$ thereafter. $^{40}$

To calculate the benefit, I combine estimates from the CPS-ATUS data on reading with external data on test score performance and wages. The median household in the CPS-ATUS lives 3 to 5 miles from the library, and moving the household half closer to the library implies they would read approximately 1.5 more minutes per day. ${ }^{41}$ Taking data from the National Center for Education Statistics, I calculate the correlation between daily reading time and test score achievement and estimate that the 1.5 minute

\footnotetext{
${ }^{40}$ Information about the labor force population $(\mathrm{N}=365,693)$ in Monroe County was obtained from the American Fact Finder website (see http://factfinder.census.gov/). The cost of building a new library was taken from averages of construction and servicing costs of public libraries built in Monroe County in 2009 (see http://www.nysl.nysed.gov/libdev/construc/needs.htm). The amount of property tax that goes to the public library system in Monroe County is based on median house values $(\$ 122,000$, with $\$ 98$ going to public libraries through property tax payments; see http://www2.libraryweb.org/orgMain.asp?storyid=2287\&orgid=582).

${ }^{41}$ This estimate is obtained by running the reduced form regression of reading on distance and other covariates. The coefficient estimates on the distance dummies are: 1 to 2 miles: -0.0400 (s.e. $=0.0334$ ); 3 to 5 miles: $-0.0703\left(0.0301^{* *}\right) ; 6$ to 10 miles: $-0.0523\left(0.0300^{*}\right)$; and 10 plus miles: $-0.0865\left(0.0421^{* *}\right)$ Half closer when a household already lives 3 to 5 miles away implies living 1.5 to 2.5 miles away from a library. Households that live 3 to 5 miles away read 4 minutes fewer than those living less than 1 mile away, households that live 1 to 2 miles away read 2.5 minutes less than those who live less than 1 mile away. Consequently, halving the distance of the median household will increasing reading time by 1.5 minutes per day.
} 
increase in reading translates to a 0.018 standard deviation improvement in reading test scores. ${ }^{42}$ Using Blau and Kahn's (2005) estimate that a one standard deviation improvement in test scores results in a $13 \%$ increase in real wages, the 1.5 minute increase in reading translates to a $0.23 \%$ increase in wages. ${ }^{43}$ Evaluated at the average wage for all occupation categories, this translates to a $\$ 94$ per worker increase per year. Note that the benefits accrue to all workers, while the costs are incurred only by property tax payers. Moreover, only a private benefit was calculated; positive social benefits may accrue from having a more literate labor force population (increased productivity, less unemployment). It is important to note that these calculations are approximate and based on a number of simplifying assumptions. This exercise is only meant to highlight some of the considerations that policy makers who are interested in encouraging reading may take into account when determining library funding.

\section{Conclusion}

Given that recreational reading is a leisure activity that has important consequences for children and adults, educators and policy makers have an interest in understanding the factors that determine how much a person reads. One component of this decision is the availability of reading materials, and in the U.S., one of the largest sources of low cost books is public libraries. Libraries offer almost unlimited access to books, child and adult program, computers, internet, and other research resources. Although there is no per visit charge, libraries are primarily supported by the local community through property tax payments. Despite the source of these funds, widespread existence of libraries and importance attached to reading, no study prior to this has examined the impact that library use has on reading time. I quantify this effect, and in addition examine which other activities are altered by library use. Recognizing the potential importance of library resources for children, I also estimate the impact of use on the academic outcomes of elementary and secondary school students.

OLS estimates are only suggestive of the relationship between library use and the

\footnotetext{
${ }^{42}$ The correlation was calculated using daily reading rates and test score achievement on the NAEP Reading Test: Regular reading of 20 minutes per day is positively correlated with a 0.24 standard deviation increase in test scores. Test scores are normalized to be mean zero, standard deviation one. See Perie and Moran (2005). The only available information (to my knowledge) between reading time and cognitive achievement is correlation based.

${ }^{43}$ Blau and Kahn estimate a one standard deviation increase in test scores increases wage for men by $15.86 \%$ and for women by $11.51 \% ; 13 \%$ is the average. Wage estimates $(\$ 40,660)$ were obtained from the Bureau of Labor Statistics for Monroe County, NY in May 2007 at http://www.bls.gov/oes/current/oes_40380.htm\#b00-0000
} 
outcomes due to the non-random selection of individuals into library use. To obtain causal estimates, I use an IV approach where the instrument is the distance of each household to their closest public library. This first stage illustrates an intuitive, but previously undocumented fact: Households that live closer to a library are more likely to use it than those that live farther away. I provide evidence that suggests this finding is not a result of selection into distance nor that distance proxies for access/proximity to other amenities. The second stage IV estimates indicate that library use increases average daily reading by approximately 26 minutes, and this is maintained by a decrease in the amount of time spent watching television by 58 minutes. Moreover, among households with young children, library users read approximately 12 more minutes to/with children. Lastly, I find that library use is positively associated with higher homework completion rates, and negatively associated with misbehavior.

My discussion focuses on three main aspects of the results: First, I examine the direction of selection into library use. The OLS and IV results are consistent with a story where individuals that have the highest taste for reading are less likely to use the library. Second, I examine the presence of measurement error, and find that there is evidence for it, suggesting that the OLS estimates are biased toward zero. These factors provide justification for the magnitude of the IV estimates compared to the OLS estimates. Finally, I use the results in a cost-benefit analysis to highlight the potential application of this study for policy makers. 


\section{References}

[1] Bayard, Madeleine. 2006. "State Efforts to Promote Reading And Literary Activities in Communities" National Governors Association Center For Best Practices: Issue Brief.

[2] Betts, Julian R. 1995. "Does School Quality Matter? Evidence from the National Longitudinal Survey of Youth" Review of Economics and Statistics Vol. 77, No. 2, pp. 231-250.

[3] Blau, Francine and Lawrence Kahn. 2005. "Do Cognitive Test Scores Explain Higher U.S. Wage Inequality??" Review of Economics and Statistics Vol. 87, pp. 184-193.

[4] Bureau of Labor Statistics. 2007. "Leisure And Sports Activities Chart" American Time Use Charts.

[5] Brogan, Kathryn S. and Robert Lee Brewer. 2003. 2004 Writer's Market F \& W Publications.

[6] Carlton, Jim. January 15, 2009. "Folks Are Flocking to the Library, a Cozy Place to Look for a Job Books, Computers and Wi-Fi Are Free, But Staffs Are Stressed by Crowds, Cutbacks" The Wall Street Journal.

[7] Carpenter, Christopher and Phillip Cook. 2007. "Cigarette Taxes And Youth Smoking: New Evidence From National, State and Local Youth Risk Behavior Surveys" NBER Working Paper No. 13046.

[8] Celano, Donna and Susan B. Neuman. 2001. "The Role of Public Libraries in Children's Literacy Development: An Evaluation Report" Pennsylvania Library Association Technical Report. Pennsylvania Department of Education.

[9] Chute, Adrienne and Patricia Kroe. 1999. "E.D. TAB Public Libraries in the United States: Fiscal Year 1996" National Center for Education Statistics Technical Report. Washington, D.C.

[10] Chute, Adrienne and Patricia Kroe and Patricia O'Shea and Terri Craig and Michael Freeman and Laura Hardesty and Joanna Fane McLaughlin and Cynthia Jo Ramsey. 2006. "E.D. TAB Public Libraries in the United States: Fiscal Year 2004" National Center for Education Statistics Technical Report. Washington, D.C.

[11] Clark, Christina and Kate Rumbold. 2006. "Reading for Pleasure: A Research Overview" National Literacy Trust, Technical Report. London, U.K. 
[12] Conference Board. 2006. "Are They Really Ready To Work?" The Conference Board Research Reports.

[13] Cunningham, A.E. and K.E. Stanovich. 1998. "What reading does for the mind" American Educator Vol. 22, No. 1 and 2, pp. 8-154.

[14] Elley, W.B. (ed.) 1994. The IEA Study of Reading Literacy: Achievement and Instruction in Thirty-Two School Systems Pergamon, Oxford, U.K.

[15] Farber, H.S. and Gibbons, R. 1996. "Learning and Wage Dynamics" Quarterly Journal of Economics Vol. 111, pp. 1007-1047.

[16] Forsyth, Ellen 2006. "Retail Therapy of Social Inclusion: Public Libraries in Shopping Centers." Public Library Services of Austraila. Sydney, NSW.

[17] Gentzkow, Matthew and Jesse Shapiro. 2006. "Does Television Rot Your Brain? New Evidence From The Coleman Study" NBER Working Paper No. 12021.

[18] Griffiths, José-Marie and Donald King and Christinger Tomer and Thomas Lynch and Julie Harrington. 2004. "Taxpayer Return on Investment in Florida Public Libraries: Detailed Results and Study Methods-Part II" State Library and Archives of Florida Technical Report. Florida Department of State.

[19] Imbens, Guido W. and Joshua D. Angrist. 1994. "Identification and Estimation of Local Average Treatment Effects" Econometrica Vol. 62, No. 2, pp. 467-475.

[20] MacBeth, Tannis (ed.). 1996. Tuning Into Young Viewers SAGE Publications. Newbury Park, California.

[21] McCarthy, Richard C. 2007. Managing Your Library Construction. Chicago: American Library Association Publication. pp. 32-33.

[22] McMichael, Barbara Lloyd. August 23, 2004. "Something New To Check Out At The Mall: Library Books" The Christian Science Monitor.

[23] National Endowment for the Arts. 2004. "Reading At Risk: A Survey of Literary Reading in America" National Endowment for the Arts Research Division Report No. 46.

[24] Neuman, Susan B. and David K. Dickinson. 2005. Handbook of Early Literary Research Vol. Two, The Guilford Press.

[25] Olken, Benjamin. 2006. "Do Television and Radio Destroy Social Capital? Evidence from Indonesian Villages" NBER Working Paper No. 12561. 
[26] Perie, M. and R. Moran. 2005. "NAEP 2004 Trends In Academic Progress: Three Decades of Student Performance in Reading and Mathematics" U.S. Department of Education National Center for Education Statistics Technical Report 2005-464, Washington, DC: Government Printing Office.

[27] Rideout, Victoria and Elizabeth Vandewater and Ellen Wartella. 2003. "Electronic Media In The Lives of Infants, Toddlers, and Preschoolers" Kaiser Family Foundation Technical Report.

[28] Robinson, Thomas N. and Marta A. Wilde and Lisa C. Navracruz and Farish Haydel and Ann Varaday. 2001. "Effects of Reducing Children's Television and Video Game Use on Aggressive Behavior" Archives of Pediatrics and Adolescent Medicine Vol. 155 , pp. $17-23$.

[29] Smith, M. Cecil. 1994. "What Do Adults Read and Why Does It Matter?" Department of Educational Psychology, Counseling 85 Special Education: Northern Illinois University Unpublished work.

[30] Waste Energy Research Group. 2006. "Sussex Incentives Recycling And Leisure Project" Waste and Energy Research Group Technical Report Ref. 34.

[31] Waldman, Michael and Sean Nicholson and Nodir Adilov. 2006. "Does Television Cause Autism?" NBER Working Paper No. 12632.

[32] West, R.F. and K.E. Stanovich and H.R. Mitchell. 1993. "Reading in the real world and its correlates" Reading Research Quarterly Vol. 28, pp. 34-50. 
Dependent Variable: Library Use in the Past Month ( $=0$ no, $=1$ yes)

$\underline{\text { Distance (omit }<1 \text { mile) }}$

All Households

1 to 2 miles

[s.e.]

3 to 5 miles

10 plus miles

$\mathrm{N}$

$\mathrm{R}^{2}$

F-stat on

Instruments

[p-value]
$-0.0374$

$[0.0175]^{* *}$

$-0.0778$

$[0.0159]^{* * *}$

$-0.1425$

$[0.0177]^{* * *}$

$-0.1627$

$[0.0222]^{* * *}$

8,332

0.1814

$\mathrm{F}(4,50)=26.59$

[0.0000]
Households with Children Age:
$\underline{0 \text { to } 5}$
$\underline{6 \text { to } 12}$
$\underline{13 \text { to } 18}$

\begin{tabular}{|c|c|c|}
\hline 0 to 5 & $\underline{6}$ to 12 & 13 to 18 \\
\hline
\end{tabular}

$-0.0494$

$-0.0271$

$-0.0341$

[0.0356]

[0.0301]

[0.0273]

$-0.1043$

$-0.0608$

$-0.085$

$[0.0334]^{* * *}$

[0.0373]*

$[0.0285]^{* * *}$

$$
-0.2067
$$

$-0.1747$

$-0.1473$

[0.0529]***

[0.0428]***

[0.0408]***

$-0.2927$

$-0.2095$

$-0.1967$

[0.0445]***

[0.0446]***

$[0.0586]^{* * *}$

1,720

2,238

1,837

0.2314

0.1553

0.1573

Standard errors are given in brackets, adjusted for clustering by state of residence. Data comes from the merged CPS-ATUS data set. All regressions control for the variables listed in Section 3 of the text, including state f.e. The first stage regressions were estimated using a linear probaiblity model; probit estimates produce similar results. $* * *$ denotes statistically significant from zero at $1 \%$, ** at $5 \%$, * at $10 \%$. 
Dependent Variable: Library Use in the Past Month ( $=0$ no, $=1$ yes)

All

Distance (omit $<1$ mile)
$-0.0668$

$[0.012]^{* * *}$

[s.e.]

3 to 5 miles

6 to 10 miles

10 plus miles

$\mathrm{N}$

$\mathrm{R}^{2}$

F-stat on

Instruments

[p-value]

$$
\begin{gathered}
-0.1088 \\
{[0.0135]^{* * *}}
\end{gathered}
$$

$$
-0.1647
$$$$
\text { [0.0164]*** }
$$

$$
-0.2641
$$$$
[0.0176]^{* * *}
$$

$$
15,511
$$

0.1011
Urban/Suburban

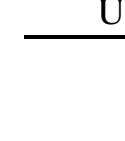

Rural

Rural

Standard errors are given in brackets, adjusted for cluster by state of residence. Data comes from the National Household Education Survey. All regressions control for the variables listed in Section 3 of the text, including state f.e. The first stage regressions were estimated using a linear probaiblity model; probit estimates produce similar results. ${ }^{* * *}$ denotes statistically sigfnificant from zero at $1 \%$, ** at $5 \%$, * at $10 \%$. 
Table 3: Reading, Television, and Neighborhood Characteristics of Households

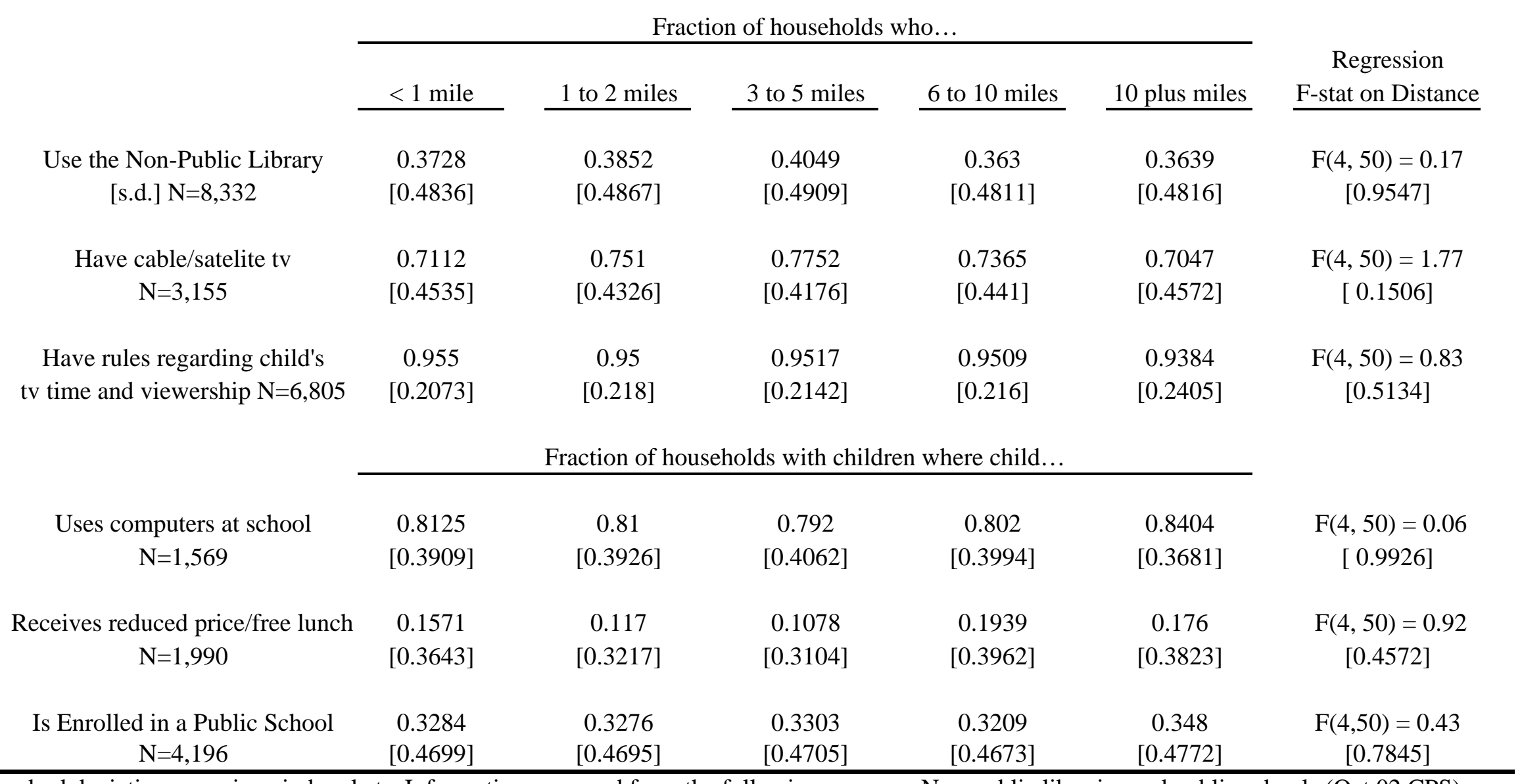

Standard deviations are given in brackets. Information was used from the following sources : Non-public libraries and public schools (Oct 02 CPS); Cable and computers (Oct 03 CPS); Lunches (Dec 02 CPS); Television rules (NHES). The sample sizes are smaller since not all households from Oct 02 were in these rotations. Moreover, for computers, lunches, and school enrollment, the sample is restricted to families with school-aged children. Television rules were only asked in households with very young children. The last column presents the F-stat and p-value on a test of the joint significance of the distance dummies, from regressions where the dependent variable is the corresponding characteristic. All regressions include the controls listed in Section 3 of the text, including state f.e. ${ }^{* * *}$ denotes statistically significant from zero at $1 \%, * *$ at $5 \%$, * at $10 \%$. 
Table 4: Monthly and Yearly Library Use by Residential History

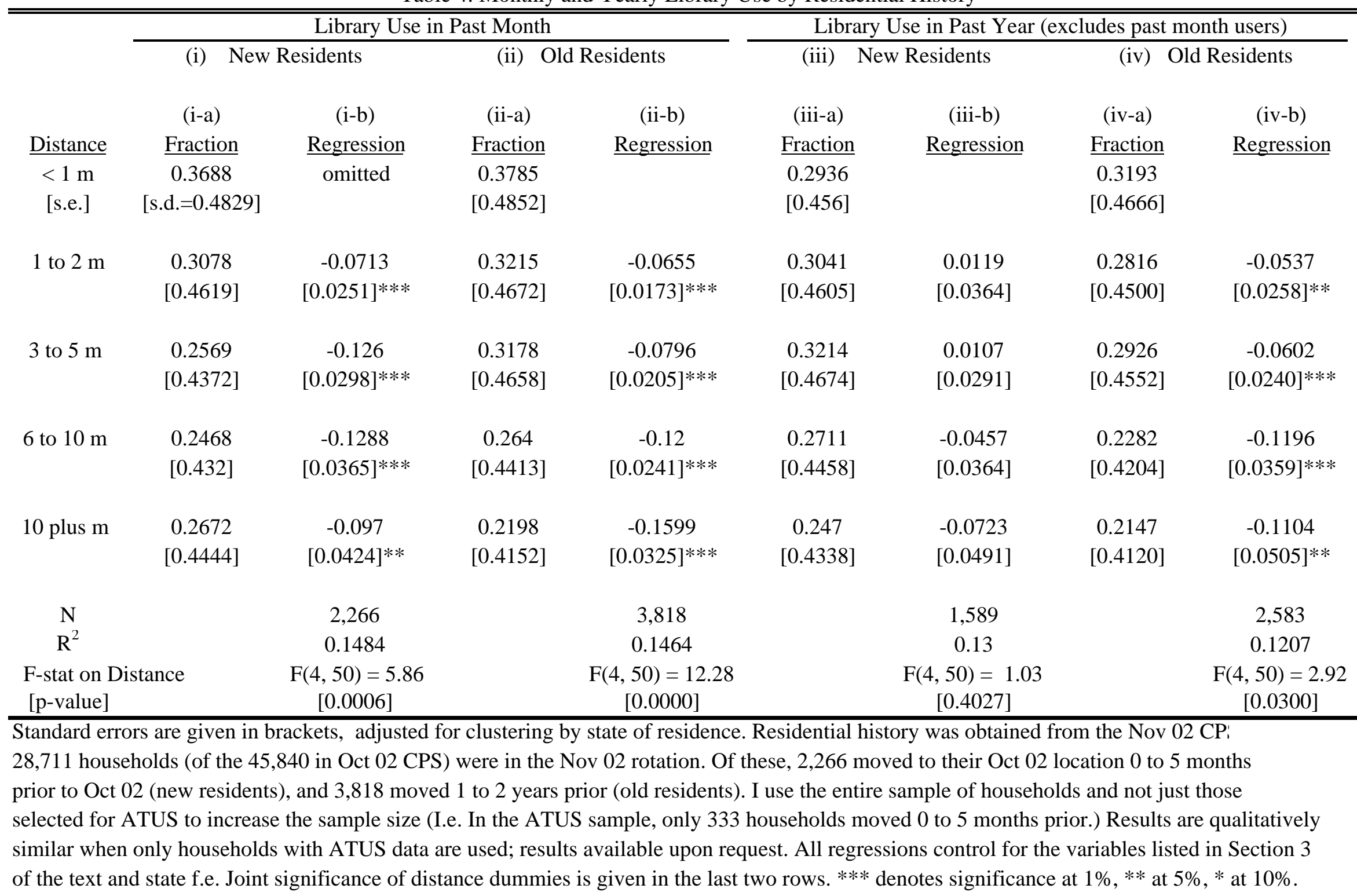


Dependent Variable: Hours spent ... on diary day (for households with children: with/to child) Independent Variable: Library use in past month ( $=0$ no, $=1$ yes)

\begin{tabular}{|c|c|c|c|c|}
\hline \multirow[b]{2}{*}{$\frac{\text { All Households }}{\mathrm{N}=8,332}$} & \multirow[b]{2}{*}{$\begin{array}{l}\text { Reading } \\
\text { [s.e.] }\end{array}$} & \multirow{2}{*}{$\begin{array}{c}\text { OLS } \\
0.1588 \\
{[0.0211]^{* * *}}\end{array}$} & \multirow{2}{*}{$\begin{array}{c}\text { IV } \\
0.4433 \\
{[0.1799]^{* * *}}\end{array}$} & \multirow{2}{*}{$\begin{array}{c}\text { Mean (hours) } \\
0.4089 \\
\text { [s.d. }=0.9824]\end{array}$} \\
\hline & & & & \\
\hline & $\begin{array}{l}\text { Television } \\
\text { [s.e.] }\end{array}$ & $\begin{array}{c}-0.2066 \\
{[0.0458]^{* * *}}\end{array}$ & $\begin{array}{c}-0.973 \\
{[0.4792]^{* *}}\end{array}$ & $\begin{array}{c}2.5142 \\
{[2.5503]}\end{array}$ \\
\hline \multicolumn{5}{|c|}{ Households with Children Age: } \\
\hline$\underline{0 \text { to } 5 \text { years old }}$ & Reading & $\begin{array}{c}0.0109 \\
{[0.0168]}\end{array}$ & $\begin{array}{c}0.2144 \\
{[0.1143]^{*}}\end{array}$ & $\begin{array}{c}0.0442 \\
{[0.2766]}\end{array}$ \\
\hline & Television & $\begin{array}{c}0.0394 \\
{[0.0908]}\end{array}$ & $\begin{array}{c}0.2798 \\
{[0.6875]}\end{array}$ & $\begin{array}{c}0.8618 \\
{[1.5263]}\end{array}$ \\
\hline \multirow[t]{2}{*}{$\underline{6 \text { to } 12 \text { years old }}$} & Reading & $\begin{array}{c}0.0095 \\
{[0.0119]}\end{array}$ & $\begin{array}{c}-0.0363 \\
{[0.0903]}\end{array}$ & $\begin{array}{c}0.0461 \\
{[0.2440]}\end{array}$ \\
\hline & Television & $\begin{array}{l}-0.0358 \\
{[0.0615]}\end{array}$ & $\begin{array}{c}0.5674 \\
{[0.7780]}\end{array}$ & $\begin{array}{c}0.8368 \\
{[1.5010]}\end{array}$ \\
\hline \multirow[t]{2}{*}{13 to 18 years old } & Reading & $\begin{array}{c}0.018 \\
{[0.0106]^{*}}\end{array}$ & $\begin{array}{c}-0.1181 \\
{[0.1270]}\end{array}$ & $\begin{array}{c}0.0352 \\
{[0.2048]}\end{array}$ \\
\hline & Television & $\begin{array}{c}0.0722 \\
{[0.0971]}\end{array}$ & $\begin{array}{c}0.7959 \\
{[0.6658]}\end{array}$ & $\begin{array}{c}0.6517 \\
{[1.3536]}\end{array}$ \\
\hline
\end{tabular}

Standard errors are given in brackets, adjusted for clustering by state of residence. All coefficients are in hours, and all regressions include the controls listed in Section 3, including state f.e.

Hours of reading and television are restricted to be less than 14 hours, resulting in a sample size of $\mathrm{N}=8,332$. The last column displays the unconditional averages for these activities.

$* * *$ denotes statistically significant from zero at $1 \%$, ** at $5 \%$, * at $10 \%$. 
Table 6: OLS \& IV Estimates: Other Leisure and Non-Leisure Activities

\begin{tabular}{|c|c|c|c|c|c|c|c|}
\hline & OLS & IV & Mean (hours) & & OLS & IV & Mean (hours) \\
\hline \multicolumn{4}{|c|}{ Leisure Activities } & \multicolumn{4}{|c|}{ Non-Leisure Activities } \\
\hline $\begin{array}{l}\text { Socializing } \\
\text { [s.e.] }\end{array}$ & $\begin{array}{l}0.0156 \\
{[0.035]}\end{array}$ & $\begin{array}{c}0.2691 \\
{[0.3399]}\end{array}$ & $\begin{array}{c}0.6819 \\
\text { [s.d. }=1.3721]\end{array}$ & $\begin{array}{l}\text { Sleeping } \\
\text { [s.e.] }\end{array}$ & $\begin{array}{c}-0.0515 \\
{[0.0434]}\end{array}$ & $\begin{array}{c}0.5956 \\
{[0.4242]}\end{array}$ & $\begin{array}{c}8.6476 \\
{[1.8391]}\end{array}$ \\
\hline $\begin{array}{l}\text { Arts and } \\
\text { Entertainment }\end{array}$ & $\begin{array}{c}0.0178 \\
{[0.0174]}\end{array}$ & $\begin{array}{c}-0.003 \\
{[0.1293]}\end{array}$ & $\begin{array}{c}0.1218 \\
{[0.653]}\end{array}$ & Housework & $\begin{array}{c}-0.0187 \\
{[0.0226]}\end{array}$ & $\begin{array}{c}0.1655 \\
{[0.2452]}\end{array}$ & $\begin{array}{c}0.6173 \\
{[1.2503]}\end{array}$ \\
\hline $\begin{array}{l}\text { Relax, play games, } \\
\text { music, write }\end{array}$ & $\begin{array}{c}0.0013 \\
{[0.0262]}\end{array}$ & $\begin{array}{c}0.3937 \\
{[0.2738]}\end{array}$ & $\begin{array}{c}0.4645 \\
{[1.1941]}\end{array}$ & Eat \& Drink & $\begin{array}{c}0.0179 \\
{[0.0187]}\end{array}$ & $\begin{array}{c}0.1832 \\
{[0.2197]}\end{array}$ & $\begin{array}{c}1.1339 \\
{[0.8678]}\end{array}$ \\
\hline $\begin{array}{l}\text { Computer } \\
\text { \& Internet }\end{array}$ & $\begin{array}{c}0.0055 \\
{[0.0152]}\end{array}$ & $\begin{array}{l}0.2375 \\
{[0.178]}\end{array}$ & $\begin{array}{c}0.1563 \\
{[0.6776]}\end{array}$ & $\begin{array}{l}\text { Research Shop } \\
\text { \& Fin Mgmt }\end{array}$ & $\begin{array}{c}0.0178 \\
{[0.0112]}\end{array}$ & $\begin{array}{c}-0.1142 \\
{[0.0984]}\end{array}$ & $\begin{array}{c}0.0577 \\
{[0.4086]}\end{array}$ \\
\hline Hobby & $\begin{array}{c}-0.0015 \\
{[0.0107]}\end{array}$ & $\begin{array}{c}0.0566 \\
{[0.0665]}\end{array}$ & $\begin{array}{c}0.0332 \\
{[0.3935]}\end{array}$ & $\begin{array}{l}\text { Working } \\
(\mathrm{N}=5,537)\end{array}$ & $\begin{array}{c}0.086 \\
{[0.1153]}\end{array}$ & $\begin{array}{c}-0.3839 \\
{[0.8326]}\end{array}$ & $\begin{array}{c}4.0683 \\
{[4.2394]}\end{array}$ \\
\hline $\begin{array}{l}\text { Exercise } \\
\text { \& Sports }\end{array}$ & $\begin{array}{l}0.0156 \\
{[0.035]}\end{array}$ & $\begin{array}{c}0.2691 \\
{[0.3399]}\end{array}$ & $\begin{array}{c}0.6819 \\
{[1.3721]}\end{array}$ & $\begin{array}{l}\text { Job Search } \\
\text { (unemp; N=402 ) }\end{array}$ & $\begin{array}{c}0.1251 \\
{[0.1573]}\end{array}$ & $\begin{array}{c}1.4536 \\
{[1.0856]}\end{array}$ & $\begin{array}{c}0.38 \\
{[1.1625]}\end{array}$ \\
\hline \multirow[t]{2}{*}{ Volunteer } & $\begin{array}{c}0.0517 \\
{[0.0164]^{* * *}}\end{array}$ & $\begin{array}{c}-0.1381 \\
{[0.1782]}\end{array}$ & $\begin{array}{c}0.1548 \\
{[0.7716]}\end{array}$ & $\begin{array}{l}\text { School } \\
\text { (in sch; N=992) }\end{array}$ & $\begin{array}{c}-0.05 \\
{[0.1609]}\end{array}$ & $\begin{array}{c}-0.7192 \\
{[1.1728]}\end{array}$ & $\begin{array}{c}1.6264 \\
{[2.7912]}\end{array}$ \\
\hline & & & & $\begin{array}{l}\text { Hwk \& Research } \\
\text { (in sch; N=992) }\end{array}$ & $\begin{array}{l}-0.0456 \\
{[0.0378]}\end{array}$ & $\begin{array}{c}-0.0362 \\
{[0.1578]}\end{array}$ & $\begin{array}{c}0.0633 \\
{[0.5323]}\end{array}$ \\
\hline
\end{tabular}

Standard errors are in brackets, adjusted for clustering by state. All regressions include the controls listed in Section 3 of the text and state f.e. Dependent variables are restricted to be less than 14 hours. This limits the sample size for socializing, exercise, and housework to $\mathrm{N}=8,331$; relaxing to $\mathrm{N}=8,325$; sleeping to $\mathrm{N}=8,076$ (also restricted to be $>4$ hours, which excludes less than $1 \%$ of observations). All other regressions have $\mathrm{N}=8,332$, except those conditional on employment, labor force participation, and school enrollment. $* * *$ denotes statistically significant from zero at $1 \%, * *$ at $5 \%, *$ at $10 \%$. 
Table 7: OLS \& IV Estimates: Academic Outcomes

\begin{tabular}{|c|c|c|c|c|c|c|c|c|c|}
\hline & \multirow{2}{*}{\multicolumn{3}{|c|}{ Urban and Suburban }} & & & & & & \\
\hline & & & & \multicolumn{3}{|c|}{ Rural } & \multicolumn{3}{|c|}{ All } \\
\hline & $\underline{\mathrm{OLS}}$ & $\underline{\mathrm{IV}}$ & Mean & $\underline{\mathrm{OLS}}$ & $\underline{\mathrm{IV}}$ & Mean & $\underline{\mathrm{OLS}}$ & $\underline{\mathrm{IV}}$ & Mean \\
\hline \multicolumn{10}{|c|}{ Do More Homework/Week than Average for Peers (=0 no, =1 yes) * ages 7and up * } \\
\hline $\begin{array}{c}\text { Library } \\
\text { [s.e.] }\end{array}$ & $\begin{array}{c}0.0635 \\
{[0.0120]^{* * *}}\end{array}$ & $\begin{array}{c}0.1743 \\
{[0.1031]^{*}}\end{array}$ & $\begin{array}{c}0.3881 \\
\text { [s.d. }=0.4873] \\
\mathrm{N}=10,607\end{array}$ & $\begin{array}{c}0.0405 \\
{[0.0148]^{* * *}}\end{array}$ & $\begin{array}{c}0.067 \\
{[0.0961]}\end{array}$ & $\begin{array}{c}0.306 \\
{[0.4609]} \\
N=3,705\end{array}$ & $\begin{array}{c}0.0562 \\
{[0.0098]^{* * *}}\end{array}$ & $\begin{array}{c}0.1133 \\
{[0.0682]^{*}}\end{array}$ & $\begin{array}{c}0.3668 \\
{[0.4819]} \\
\mathrm{N}=14,312\end{array}$ \\
\hline \multicolumn{10}{|c|}{ Average Grades $(=1 \mathrm{~F} . .=5 \mathrm{~A}) *$ ages 6 and up * } \\
\hline Library & $\begin{array}{c}0.0895 \\
{[0.0187]}\end{array}$ & $\begin{array}{c}0.0411 \\
{[0.1369]}\end{array}$ & $\begin{array}{c}4.1415 \\
{[0.8648]} \\
N=9,257\end{array}$ & $\begin{array}{c}0.0366 \\
{[0.0295]}\end{array}$ & $\begin{array}{c}-0.1059 \\
{[0.2148]}\end{array}$ & $\begin{array}{c}4.1758 \\
{[0.8743]} \\
N=3,349\end{array}$ & $\begin{array}{c}0.0767 \\
{[0.0166]^{* * *}}\end{array}$ & $\begin{array}{c}0.0114 \\
{[0.1126]}\end{array}$ & $\begin{array}{c}4.1506 \\
{[0.8674]} \\
\mathrm{N}=12,606\end{array}$ \\
\hline \multicolumn{10}{|c|}{ Behavior Problems in School (=0 no, =1 yes) } \\
\hline Library & $\begin{array}{c}-0.0033 \\
{[0.0076]}\end{array}$ & $\begin{array}{c}-0.1685 \\
{[0.0614]^{* * *}}\end{array}$ & $\begin{array}{c}0.2267 \\
{[0.4187]} \\
\mathrm{N}=11,551\end{array}$ & $\begin{array}{c}-0.0007 \\
{[0.0129]}\end{array}$ & $\begin{array}{c}0.0117 \\
{[0.0811]}\end{array}$ & $\begin{array}{c}0.1808 \\
{[0.3849]} \\
N=3,960\end{array}$ & $\begin{array}{c}-0.0014 \\
{[0.0078]}\end{array}$ & $\begin{array}{c}-0.0909 \\
{[0.0456]^{* *}}\end{array}$ & $\begin{array}{c}0.215 \\
{[0.4108]} \\
\mathrm{N}=15,511\end{array}$ \\
\hline \multicolumn{10}{|c|}{ Ever Repeated Grade (=0 no, =1 yes) } \\
\hline Library & $\begin{array}{c}-0.0154 \\
{[0.0074]^{* *}}\end{array}$ & $\begin{array}{c}0.0389 \\
{[0.0412]}\end{array}$ & $\begin{array}{c}0.1218 \\
{[0.3271]} \\
\mathrm{N}=11,551 \\
\end{array}$ & $\begin{array}{c}-0.0104 \\
{[0.0089]}\end{array}$ & $\begin{array}{c}-0.0508 \\
{[0.0615]}\end{array}$ & $\begin{array}{c}0.1131 \\
{[0.3167]} \\
\mathrm{N}=3,960\end{array}$ & $\begin{array}{c}-0.0136 \\
{[0.0063]^{* *}}\end{array}$ & $\begin{array}{c}0.0059 \\
{[0.0341]}\end{array}$ & $\begin{array}{c}0.1196 \\
{[0.3245]} \\
\mathrm{N}=15,511\end{array}$ \\
\hline
\end{tabular}


Dependent Variable: Hours spent...

Independent Variable: Library Use (=0 no, $=1$ yes)

Comparison of Library Use Response

\begin{tabular}{|c|c|c|c|}
\hline \multirow[b]{3}{*}{$\begin{array}{c}\text { Reading } \\
\text { [s.e] }\end{array}$} & \multicolumn{2}{|c|}{ OLS } & \\
\hline & 1st Answer & 2nd Answer & \\
\hline & $\begin{array}{c}0.1543 \\
{[0.0207]^{\star \star \star}}\end{array}$ & $\begin{array}{c}0.1584 \\
{[0.0211]^{\star \star \star}}\end{array}$ & \\
\hline \multirow[t]{4}{*}{$\mathrm{R}^{2}$} & $\begin{array}{c}8,332 \\
0.1486\end{array}$ & $\begin{array}{c}8,332 \\
0.1489\end{array}$ & \\
\hline & \multicolumn{3}{|c|}{ Comparision of CPS \& ATUS Respondent Samples } \\
\hline & \multicolumn{3}{|c|}{ OLS } \\
\hline & Full Sample & Same Respondent & Different Respondent \\
\hline $\begin{array}{l}\text { Reading } \\
\text { [s.e] }\end{array}$ & $\begin{array}{c}0.1584 \\
{[0.0211]^{\star \star \star}}\end{array}$ & $\begin{array}{c}0.2154 \\
{[0.0328]^{\star \star \star}}\end{array}$ & $\begin{array}{c}0.0899 \\
{[0.0284]^{\star \star \star}}\end{array}$ \\
\hline $\mathrm{N}$ & 8,332 & 4627 & 3705 \\
\hline $\mathrm{R}^{2}$ & 0.1489 & 0.168 & 0.1475 \\
\hline
\end{tabular}

Standard errors are given in brackets, adjusted for clustering by state. All regressions control for the variables listed in Section 3 of the text, including state f.e. The upper half of the table displays the estimates when two measures of library use are used. The lower half displays the results for 3 samples:

(i) full sample, (ii) households where CPS \& ATUS respondent are the same person, (iii) households where the CPS \& ATUS respondent are different people. *** denotes statistically significant from zero at $1 \%,{ }^{* *}$ at $5 \%,{ }^{*}$ at $10 \%$. 

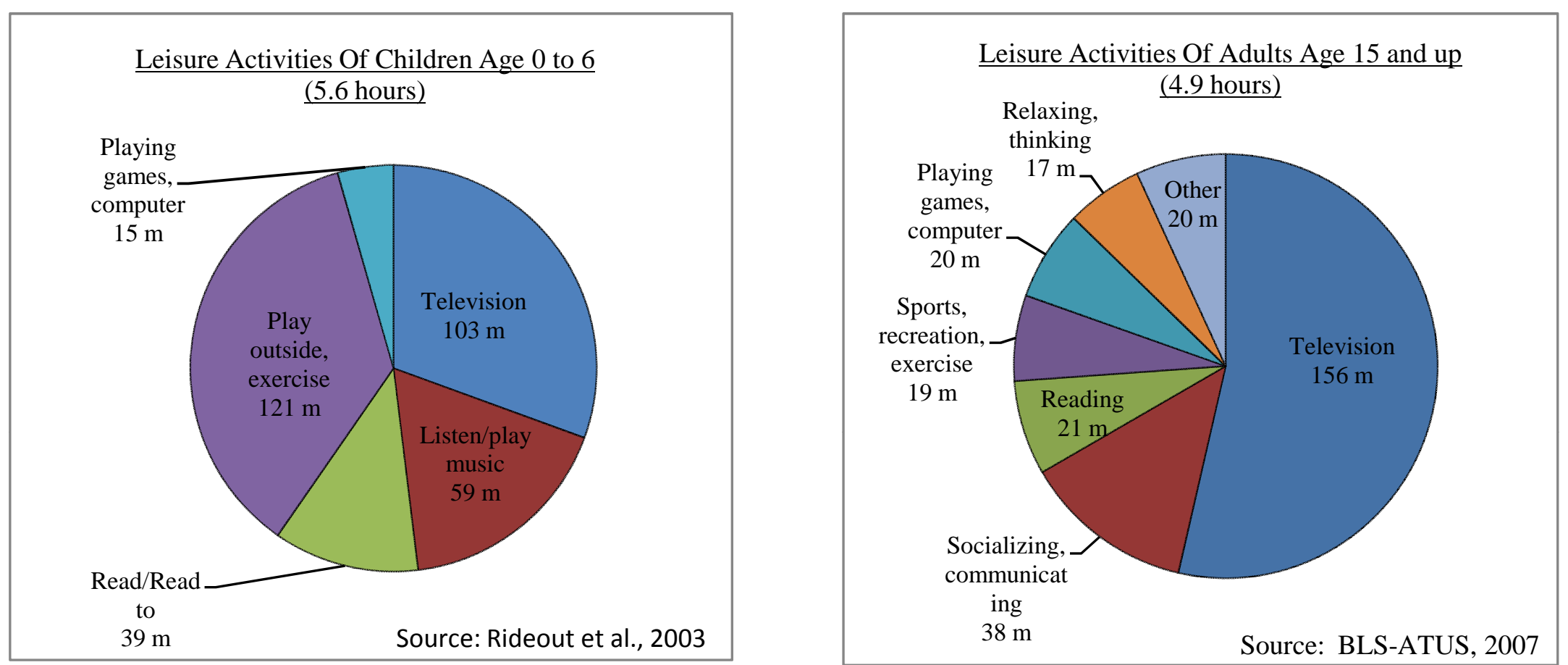

The two charts depict the average time (minutes) spent on various leisure activities for children age 0 to 6 (left) and adults age 15 and up (right). The averages are unconditional and are averaged across all days of the week. 